\title{
KPI-TREE MODELL FEJLESZTÉSE PREDIKCIÓS ELJÁRÁSOK ALKALMAZÁSÁVAL
}

\author{
Gáspár Sándor - Thalmeiner Gergő
}

\begin{abstract}
Absztrakt: A kontrolling fejlődése az elmúlt években a Big Data, mesterséges intelligencia, a különböző matematikai statisztikai módszertanok fejlődése és a digitalizáció által olyan modelleket hozott létre a menedzsment számára, amelyek hatékonyabb döntéshozást és tervezési folyamatot tettek lehetővé. A különböző predikciós, illetve ok-okozati kontrolling modellek a döntéshozáshoz szükséges információtartalmat nagymértékben növelték. Innovációs folyamatok által számos új, különböző operatív mérési lehetőség és adatszerzési forrás jelent meg. Ugyanakkor ezen adatok önmagukban nagyon kevésszer hordoznak információtartalmat. Összességében egy strukturált rendszerben, illetve modellben viszont olyan információhalmazzá válhatnak ezek az adatok, amelyek akár képesek egy teljes szervezet müködési modelljének ok-okozati összefüggéseit elemezni és a különböző menedzsment funkciókat a tervezéstől egészen az ellenőrzésig támogatni.

A KPI-tree egy olyan kontrolling modell, amelyet a legtöbb esetben az iparban tevékenykedő multinacionális szervezetek alkalmaznak, illetve fejlesztenek. A KPI-tree a különböző módokon megfogalmazott KPI mutatókat adott célok és korrelációk mentén csoportokba szervezi és egy egymásra épülő logikai felépítettség mellett rendszerezi. A különbözö módokon mért KPI mutatószámokat mind a szakirodalom, mind pedig a vállalati gyakorlat határozza meg. A Big Data és az ipar 4.0 által generált adatok viszont az új KPI-ok megalkotására és a már meglévő KPI-ok akár percre pontos adatgyüjtésére is lehetőséget adnak. Ezen új KPI-ok lehetőséget adnak mind a napi szintü terv-tény összehasonlításra és az ezen alapuló objektív napi szintü elemzésre, illetve a különböző lean menedzsment és egyéb gazdálkodásszervezési módszer mérésére.

A KPI-tree modellből nyert adatok felhasználásával és implementálásával a különböző predikciós modellek segítségével hatékonyan elörejelezhetővé válik a jövőbeli teljesítmény mértéke és a céltól való eltérése. Továbbá a különböző matematikai statisztikai módszerek és a fejlett Big Data elemző algoritmusok képesek elöre jelezni a KPI-tree adataiból kinyerhető müködési anomáliákat is.
\end{abstract}

Abstract: The development of controlling over the past few years through Big Data, artificial intelligence, the development of various mathematical statistical methodologies, and digitalization has created models for management that have allowed for more efficient decision-making and planning. Various prediction and causal controlling models greatly increased the information content needed to make decisions. Through innovation processes, a number of new operational measurement opportunities and data acquisition sources have emerged. However, these data alone carry very little information content. On the other hand, in a structured system or model, this data can become a set of information that can even analyze the causal relationships of a whole organization's operating model and support various management functions from design to control.

The KPI tree is a controlling model used and developed in most cases by multinational organizations operating in the industry. The KPI tree organizes KPIs, formulated in different ways, into groups of objectives and correlations with a logical structure built on one another. KPIs measured in different ways are determined by both the literature and corporate practice. The data generated by Big Data and Industry 4.0, on the other hand, allows for the creation of new KPIs and the collection of existing KPIs up to the minute. These new KPIs provide an opportunity to both compare daily plan- fact and objective based daily analysis based on it, as well as to measure various lean management and other business management methods.

By utilizing and implementing data from the KPI tree model, various prediction models can effectively predict future performance and deviation from the target. In addition, various mathematical statistical methods and advanced Big Data parsing algorithms are able to predict operational anomalies that can be extracted from KPI tree data.

DOI: $10.14232 /$ jtgf.2020.1-2.113-124 
Kulcsszavak: kontrolling, KPI menedzsment, KPI-tree, predikció, SAP, neurálisháló

Keywords: controlling, KPI management, KPI tree, prediction, SAP, neural network

\section{Bevezetés}

Napjainkban a kontrolling, mint a menedzsment tudományok egyik fontos ága egy kiterjedt és széleskörü változáson megy keresztül. A különböző matematikai, informatikai megoldások lehetővé teszik a szervezetek számára azt, hogy képessé váljanak a különböző rendszereknek a holisztikus kiterjesztésére. Az információs rendszerek által felhalmozott adatokból különböző struktúrák mentén szükséges olyan információkat kinyerni, amelyek relevanciájukkal elösegítik a menedzsment döntéshozását ez által pedig a termelékenyebb, hatékonyabb szervezeti müködést idéznek elő.

A kontrolling fejlődő szerepkörével többek között lehetővé kell tegye azt is, hogy a tervezés, az ellenőrzés és az információellátás ne csak izolált rendszerként müködjenek, hanem egymásra épülve támogassák a vállalati célok elérését. Egy összehangolt kontrolling mechanizmus kiépítése folyamatos fejlesztési tevékenység, amely hozzásegíti a szervezetet ahhoz, hogy egy-egy fejlesztési, bevezetési ciklus eredményeként szervezetspecifikus irányítási mechanizmussal rendelkezzen (Blumné-Zéman, 2014). Csak is olyan kontrolling rendszer lehet hatékony, amelyet a stratégiai célok és az azokat szolgáló folyamatok kontrollálására hoznak létre. Önmagában ugyan a kontrolling rendszerek nem lendítik fel a szervezetek müködését, hiányuk azonban azt eredményezi, hogy az üzleti hatékonyság nem bontakozhat ki (Véry, 2012). Jelenleg azonban a kontrolling szerepe változásokon megy keresztül, melyben a kihívásokat a nagyobb terjedelmü adathalmazok, kiterjedt feladatok (stratégiaalkotás, kockázatkezelés, fenntarthatóság szemlélete), valamint a jövőorientáltság (algoritmusok által támogatott predikciós modellek használata) jelentik.

Kutatási célunk, hogy kvalitatív módszert alkalmazva egy KPI-tree struktúra esettanulmányán, feltárásán keresztül megvizsgáljuk, milyen eljárások lehetségesek a modell prediktív továbbfejlesztésére. Tanulmányunkban a releváns szakirodalom feldolgozását követően, feltártunk egy KPI-tree esettanulmányt egy szervezet működésében, amelyet teoretikus módon prediktív módszerekkel tovább bővítettünk.

\subsection{A digitalizáció és a Big Data jelentősége}

Az úgynevezett Big Data fogalom története már 2003 környékén elkezdődött, a Google által használt GFS (Google Distributed File System) publikálásával (Sanjay et al., 2003). Ebben az időben rendelkezésre álló technológiai rendszerrel, egy 1 milliárd oldal adatait tartalmazó kereső rendszer csak nagyon magas hardver és üzemeltetési költségek mellett tudott volna müködni. A költségek nagyrészét elsősorban a webkereső által előállított óriási méretü fájlok okozták, melyek kezelése az akkori fájlrendszerekben vagy adatbázisokban csak nehézkesen és hosszadalmasan volt megoldható. A hangsúly az akkori technológia skálázhatóságán volt, mivel ebben a méretarányban a folyamat már körülményesnek és költségesnek 
bizonyult. A GFS rendszere erre a kihívásra nyújtott megoldást, megkönnyítette az ilyen óriási fájlokkal való munkavégzést. A folyamatos fejlesztéseknek köszönhetően a létrejövő rendszerek már kinőték a webkeresés problematikáját és a 2006-os Hadoop alprojekt nevezetü fejlesztések során már függetlenedtek a webkeresés szemléletétől. A projekt sikerességét tükrözi, hogy 2008-ban több cég, közöttük a Facebook vagy a New York Times is bejelentette a Hadoop technológia gyakorlatban történő alkalmazását (White, 2012).

Lényegében a Big Data a nagy mennyiségben rendelkezésre álló adat felhasználásakor fellépő technológiai skálázódási problémára adott válaszként játszott fontos szerepet. Ezt követően még jelentős ideig ez volt a Big Data fö alkalmazási területe, ugyanakkor ez még nem indokolná a robbanásszerü népszerüséget. Közismertségének kulcsa abban rejlik, hogy a szervezetek többsége igényt tart a különböző elemzések, kimutatások készítésére, melyek alapja a nagy mennyiségü tárolt és feldolgozható formájú adat. A technológia fejlődésével, a Hadoop és a Big Data elterjedésével és elemzés szemléletủ felhasználásával a szervezetek egyre több adatot kezdtek el gyüjteni, rögzíteni és feldolgozni (Stadller, 2015).

A digitalizáció hatására számtalan új információforrás keletkezésével és az egyre olcsóbb technikai eszközök kombinációjával új korszak tárul elénk. Olyan eszközök, mint például a mobiltelefonok, az online vásárlás folyamata, a szociális hálózatok, az elektronikus kommunikáció vagy a GPS technológia, müködésük során mind-mind adatforgalmat hoznak létre. Ezek az adatok jellemzően strukturálatlan formában, nem egy adatbázisban összpontosulva hatalmas mennyiségü jelként vannak jelen és csak a kiaknázásra, felhasználásra várnak. Az adatok keletkezéséhez, adatmennyiség növekedéséhez nagymértékben hozzájárul a digitalizáció, az információs és kommunikációs technológiák fejlödése, melyek az utóbbi években komoly változásokon mentek keresztül. A technológiák korszerüsödésével elérhetőbbé vált, hogy ez a hatalmas mennyiségben létrejövő adat összegyüjthetővé, feldolgozhatóvá, tárolhatóvá és számunkra megfelelő módon rendezhetővé váljon. Az adatok feldolgozása által, elemzések létrehozásával a szervezetek értékes információkhoz juthatnak (Mayer-Schönberger-Kenneth, 2014).

Egy megfogalmazás szerint: „,a Big Data nagy mennyiségü, sebességü és változatos adatok, amelyek költséghatékony módon, innovatív formában segítik a folyamatokba való jobb betekintést, a döntéshozatalt és a folyamatok automatizálását" (Gartner Inc., 2017). Egy 2001-es kutatási jelentésben Doug Laney a META Group (jelenleg Gartner) elemzője a Big Data-t három dimenzióval, azaz mennyiség (volume), változatosság (variety), sebesség (velocity) szerint határozta meg, melyet az angol elnevezések kezdőbetüivel 3V-definíciónak is szoktak nevezni.

Maga az adatfeldolgozás a szervezetek egyik legfontosabb feladata, ennek során két fö kategóriát különböztetnek meg: adatok kezelését és az adatok elemzését. Az adatkezelés során a hangsúly az adatok olyan kezdetleges szintü alkalmazásán (gyüjtésén, tárolásán) van, amelynek célja, hogy az esetleges jövőbeli feldolgozásukat tegye lehetővé. Az adatok elemzésének lényege pedig az, hogy az 
adatok feldolgozása által a szervezetek részletesebb betekintést nyerhessenek a folyamataikba és alkalmazható tudást szerezzenek, amelyet implementálva folyamataik hatékonyabbá válhatnak. A két cél között fellehetö különbségek mellett a nagy mennyiségü adatok feldolgozásával kapcsolatosan számos közös kihívás található. Az alábbiakban néhány fontosabb kihívási tényezőt ismertetünk.

Algoritmusok: Elmondható, hogy minden számítógépes feldolgozás középpontjában az algoritmusok állnak. Annak ellenére, hogy a közelmúltban komoly elörelépések történtek az informatika, az adatbányászat, az elemzés és az egyéb tudományágak terén, az algoritmikus feldolgozás még mindig viszonylag korlátozott feladatokra alkalmas, ahhoz képest, mint amennyi adat létrejön.

- Skálázhatóság. A skálázható feldolgozó rendszerek megfelelnek a növekvő adatokból származó feldolgozási igényeknek és kihívásoknak, illetve rugalmas módon bővíthetők a müködés során felmerülő igényekhez. A szervezetek többségének a legmegfelelőbb bővítés lineáris, ez azt feltételezi, hogy az erőforrásigény lineárisan arányos az adatok növekedésével.

- Időbeliség. Az időbeli követelmények felállítását követően az eredmények két fő feldolgozási módba sorolhatók: online és offline feldolgozásba. Az online mód az adatok azonnali feldolgozására utal, valós idejü rendszerek használatával az adatok azonnali elérhetővé tételével. Az offline mód az adatfeldolgozás során némi átfutási, késleltetési időt követően bocsájtja rendelkezésre az adatokat.

\subsubsection{Változások hatása}

A kontrolling rendszerek egyik legfontosabb feladata az elörejelzések készítése, amely az idő teltével több lépcsőben, különböző fejlettségi szinteken ment keresztül. A kezdetben még csak megérzésen alapuló elörejelzéseket (Forecasting 1.0) felváltotta az Excel alapú előrejelzések készítése (Forecasting 2.0). A módszertani fejlődés során következő lépéseként az üzleti intelligencia rendszerekben történő elörejelzések (Forecasting 3.0) következtek. Az elörejelzések legújabb szintje pedig a (Forecasting 4.0), ami prediktív elemzési módszerekkel, fejlett statisztikai algoritmusok támogatásával készül. Ez azt jelenti, hogy a nagy adathalmazok felhasználásával, algoritmusok által feldolgozott, statisztikai-matematikai számításokkal automatizált elörejelzések sokasága készíthető. A forecasting által felgyorsul és leegyszerüsödik az elörejelzések készítése, így rendszeresebben lehet forecast-tény eltéréseket vizsgálni. Ennek hatására az akciókényszer nő, a részletes és pontos előrejelzések hatására a szervezetek hatékonyabban tudnak reagálni a piaci hatásokra. Ebböl következően a szervezeti irányítás paradigmaváltáson megy keresztül, analitikus-reaktív helyett proaktív-előremutatóvá fejlődik (Gulyás, 2017). A megalapozott előrejelzések készítéséhez az egyik legfontosabb eszköz az úgynevezett Key Performance Indicators (röviden: KPI azaz kulcsmutatók, kulcs teljesítménymutatók vagy kulcsfontosságú teljesítménymutatók) meghatározása. A KPI-ok alatt olyan mutatószámok meghatározását értjük, amelyek a folyamatokról szolgáltatnak specifikus információt a menedzsment számára. A mutatószámokat 
többek között felhasználják a stratégiaalkotás során, a következő időszak célkitüzéseinek meghatározásában, valamint azon területek jellemzésére, melyek komolyabb erőforrásokat igényelnek (Boda-Szlávik, 2005).

\subsubsection{KPI-tree}

A KPI-tree egy olyan kontrolling modell, amelyet a legtöbb esetben az iparban tevékenykedő multinacionális szervezetek alkalmaznak, illetve fejlesztenek. A treeben szereplő KPI mutatókat a modell adott célok és korrelációk mentén csoportokba szervezi (Schnellbach-Reinhart, 2015) és egy egymásra épülő logikai felépítettség mellett rendszerezi (Ante et al., 2018). A Big Data, az adatbányászás technológiai feltételeinek fejlódése és az ipar 4.0 által generált adatok új KPI-ok megalkotására és a már meglévő KPI-ok akár percre pontos adatgyüjtésére is lehetőséget adnak (Peral et al., 2017). A kulcsmutatók fontos szerepet képviselnek a napi szintü tervtény elemzésekre és az ezen alapuló objektív napi szintű kimutatásokra, illetve a gazdálkodás szervezési folyamatok mérésére is (Schnellbach-Reinhart, 2015).

A KPI-tree modell felépítésére a szakirodalom konkrétan nem határoz meg struktúrát, annak felépítése kreatív módon valósul meg. Az alábbi ábrán szemléltetünk egy lehetséges felépítési módot, mely során kiemelendő, hogy a célok fentről lefelé, a mutatók pedig lentről felfelé épülnek egymásra és oszlanak meg a különböző szinteken.

\section{1. ábra: Célok és mérési pontok a szervezeti rendszerekben}
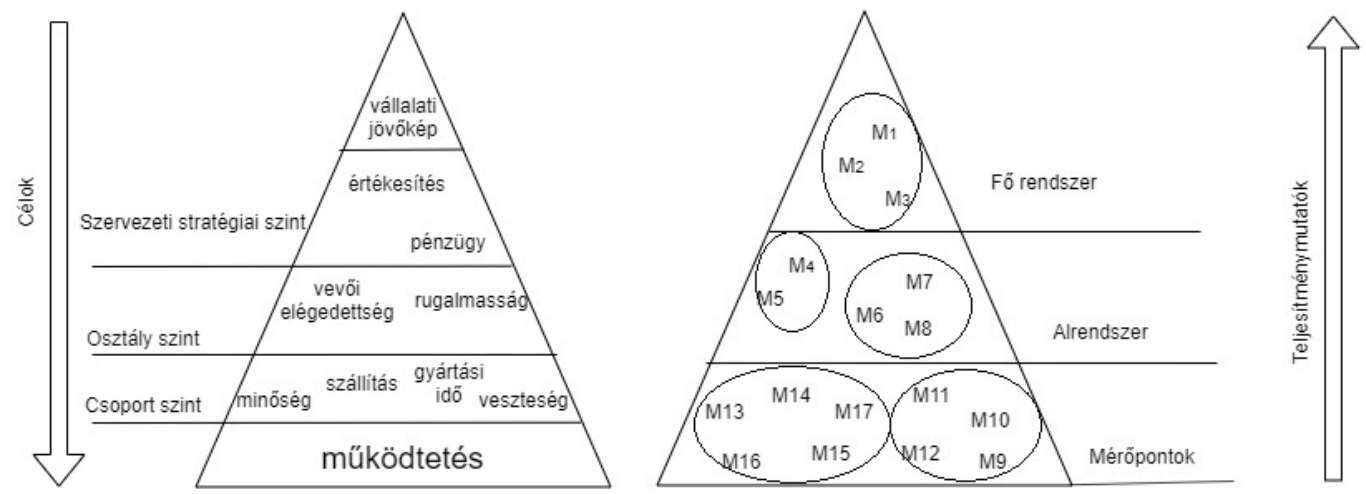

Forrás: A szerzők saját szerkesztése. / Ante et al. (2018) és Schnellbach-Reinhart (2015) alapján

\section{Kutatás és módszertan}

Kutatásunk az Innovációs és Technológiai Minisztérium (ÚNKP-19-3-I kódszámú) Új Nemzeti Kiválóság Programjának szakmai támogatásával készült.

Kutatásunk során egy kiterjesztett esetelemzést végeztünk el. Esettanulmányunkként egy Pest megyei autóalkatrészgyártó multinacionális cég szolgált. Azért választottuk a kiterjesztett esetelemzés módszert, hogy felfedezzük a meglévő elméletek, illetve a gyakorlatban alkalmazott módszerek hiányosságait és a gyakorlatban alkalmazott modellt, egy adott teoretikus szakirodalomban 
megfogalmazott modell mentén tovább fejlesszük különböző paraméterek mentén (Babbie, 2013).

Célul tüztük ki a KPI-tree modell logikai felépítésének elemzését a vizsgált autóalkatrészgyártó szervezet menedzsment rendszerében. Kutatásunkban a KPItree kulcs mutatószámának definiálása alapvetően a menedzsment döntése. Ezen döntés sokrétủ és számos funkcióra kiterjedhet. Ez az oka annak, hogy a szemléltetett ábrán „cél” KPI-oknak definiáljuk a mutatókat és a hozzá tartozó részegységeket.

\section{Eredmények}

Az ipari szervezetek számára a megfelelő információk alapján megvalósuló döntéselőkészítés, az adatok strukturálása egy olyan kihívás, amely már évtizedek óta különböző, más-más szemléletü módszereket hoz létre a piacon. A különbözö információs rendszerek hatékonyan gyüjtik és egy bizonyos struktúra alapján rendszerezik, illetve adott időszakra vonatkozóan jelentéseket készítenek a releváns információkkal a vezetöknek.

Az alábbiakban szemléltetett KPI-tree egy olyan módszer, amit a legtöbb esetben autóalkatrész gyártó szervezetek alkalmaznak, illetve fejlesztenek. A vizsgált szervezetben a KPI-tree egy belső fejlesztésű rendszerként jött létre és müködik. A KPI-tree kimondottan alkalmas lehet a különböző gazdálkodási és szervezési folyamatok mérésére, mivel egy adott struktúra mentén képes hierarchikus sorrendbe állítani a különböző csoportba tartozó KPI-okat. A termelési folyamatokhoz kötődő lean KPI-ok számos esetben determinisztikus jellegüek. Ebből következik, hogy egy adott viszonyszám definiálásával mérhető a súlyozottság és ezáltal az ok-okozati összefüggések is kiválóan riportálhatók.

A vizsgált vállalatban értékáramok alapján történik a gyártás, ami azt jelenti, hogy a különböző módokon meghatározott értékáramok, csoportok jönnek létre. Ezekben az értékáramokban egy-egy komplex szaktudással rendelkező csoport dolgozik egy adott gyártási folyamaton, illetve folyamatokon, vagy egyes esetben különböző félkész termékeken. Az értékáramokhoz tartozó kontroll rendszerekben lévő mért mutatók egy részét felsővezetők, illetve a kontrollerek előre definiálják. Az ezeken a definiálásokon kívüli mutatókat pedig az értékáram jellege és az értékáram vezetője definiálja az értékáram hatékonysága érdekében. Az értékáramok összessége és az ezekhez megfogalmazott KPI-ok összessége adja meg a szervezet gyártásának teljes kontroll rendszerét.

A KPI-tree dinamikus rendszerként müködik az értékáramok között és a hierarchiában magasabb helyet foglaló vezetők számára történő riportolás hatékonyságát segíti. Az információkat, amelyek a KPI-ok értékeléséhez szükségesek, minden nap feltöltik az adott értékáramok adminisztrátorai, ezáltal a napi szintü jelentéskészítés is lehetségessé válik. A vizsgált vállalat az SAP-t használja információs rendszerként. Ide töltik fel az adatokat a különböző értékáramba tartozó adatfelvitelre jogosult adminisztrátorok, amelyeket aztán a kontroller a KPI-tree rendszerbe integrál. A KPI-tree csúcsmutatója mindig egy olyan aggregált KPI, amely az összes értékáramban definiálva van. 
A 2. ábrán a különböző KPI-ok, illetve méröpontokhoz tartozó mutatók mind pénznemben, mind a terv-tény, mind pedig pénzbeli és mennyiségi viszonyszámaként mutatható ki. A különböző százalékos arányok kimutatásával a teljeshez viszonyított arány és az adott mutató önmagához viszonyított arányaként egy ok-okozati struktúrát is meghatároz. A célhoz viszonyított arány, ami jellemzően a múltbéli adatok és egyéb kontrollerek által igénybe vett módszerek alapján definiált cél és adott időszak tényadataiból származó információ, az adott vizsgált részelem, mutató vagy részleg fejlődését és teljesítményét fejezi ki.

\section{2. ábra: KPI-tree modell}

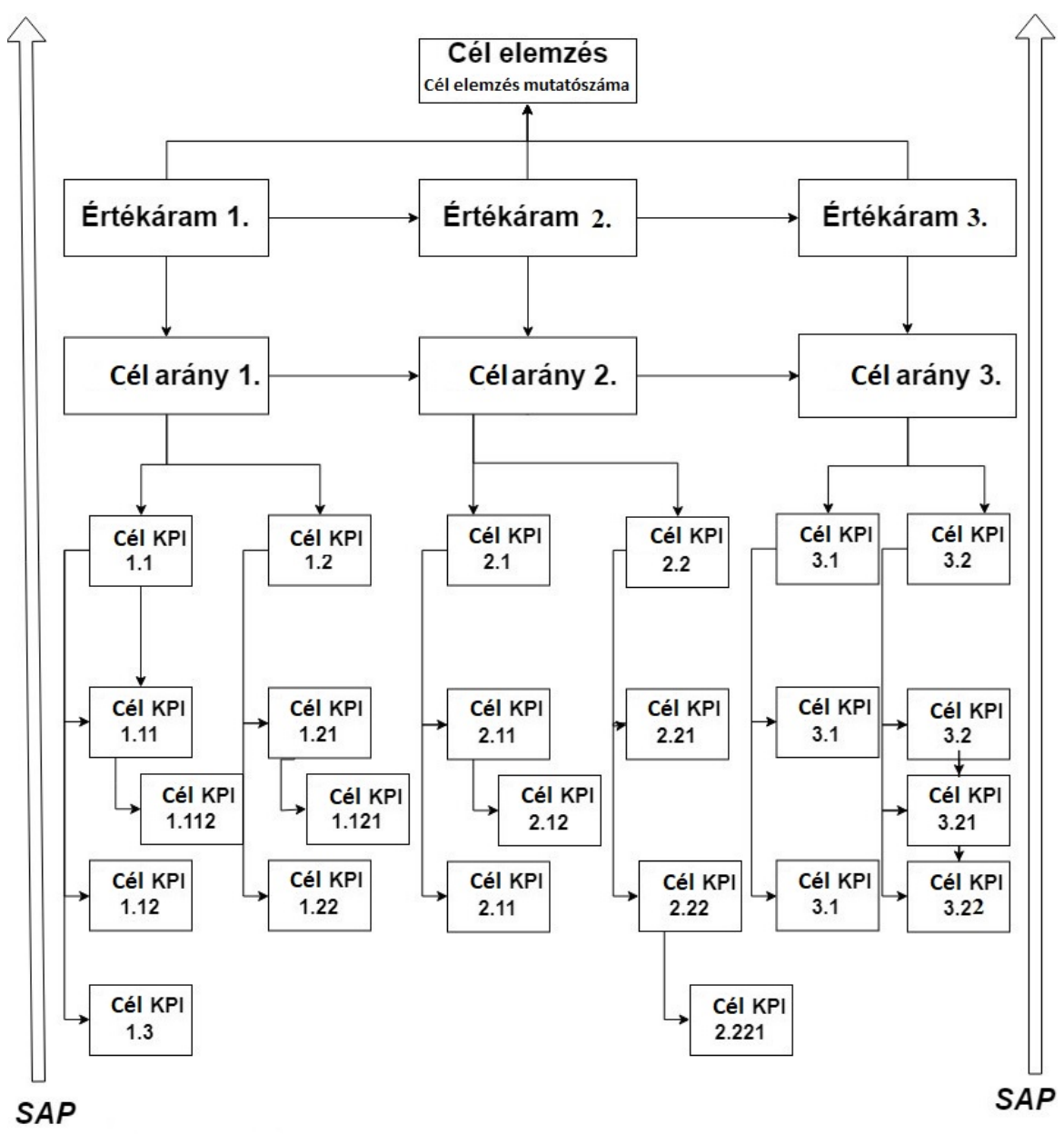

Forrás: A szerzők saját szerkesztése. / Ante at al. (2018) alapján

A KPI-tree-ből származó információk, mind időbeli mind a különböző funkcionális szintekről való felhalmozását követően egy olyan adattárházba kerülnek elraktározásra, amely meg kell, hogy feleljen a Big Data fejlődése során rendelkezésre álló különböző tulajdonságú adatok tárolásának. Ezen követelmények hardveres és szoftveres téren is kihívások elé állítja az adattárházak felépítettségét. Az adattárháznak biztosítania kell az elemzések készítéséhez szükséges adatok 
tárolását, elérhetőségét és azt, hogy az adatok az idő során ne sérüljenek, valamint az idő teltével továbbra is felhasználhatók és feldolgozhatók maradjanak. A müködés során fontos kritérium, hogy a szervezetben alkalmazott ERP rendszer (Enterprise Resource Planning, azaz vállalati erőforrástervező rendszer vagy vállalatirányítási információs rendszer; jelen esetben ez az SAP rendszere) összeköttetésben kell, hogy legyen az adattárházzal. Az adattárolás során felmerülő problémák redukálásának egyik leghatékonyabb módja lehet, ha az adattárház egy külső felhő alapú rendszer. Ezt az SAP S/4 HANA rendszer úgy biztosítja, hogy a szolgáltató már nem csak az ERP rendszerként müködő SAP szoftvert biztosítja, hanem további külső szolgáltatásként adattárházi szolgáltatást is nyújt. Ezen termék és szolgáltatás integrálásával elérhető, hogy az adatgyüjtésből és adattárolásból származó kockázatok és hibák minimalizálásra kerüljenek. Az SAP S/4 HANA egy nyílt platform és a felhő megoldáshoz tetszőleges gyártók, illetve fejlesztőktől is lehet kiegészítőket és applikációkat kapcsolni, vagyis egy belső fejlesztés során létrejövő KPI-tree rendszer is összekapcsolható vele.

A modellalkotásához szükséges releváns, kevésbé releváns, külső, belső és az akár nem feltétlenül transzparens adatok gyüjtése is. Az adatok gyüjtését követően pedig lehetőség nyílik a már strukturált adatok predeterminisztikus algoritmusokkal való feldolgozásukhoz. Az adatok strukturált gyüjtését, valamint azok elemzésbe történő bekerülését nagymértékben meghatározza az előrejelző algoritmusok által végzett elemzések kimeneti célja. A kimeneteli célt a szervezet számos kritériumnak megfelelően határozza meg. Jelenlegi kutatásunk nem terjed ki a célok meghatározására, annak összetettségének vizsgálatára. Azonban általánosan megfogalmazható, hogy a célok meghatározása legtöbb esetben top-down módszer alkalmazásával történik, de az általunk vizsgált szervezetben megfigyelhető a célok megfogalmazása esetében a top-down és bottom-up tervezési metodika is.

A KPI-tree módszer kibővítése és a módszerből származó adatok további elemzése az alábbi prediktív elemzési modellekkel történhet. Ezen módszerek nem feltétlenül univerzálisak. Jelenlegi kvalitatív kutatásunkban csak néhány szemléltető és KPI-tree módszer továbbfejlesztésére alkalmas prediktív elemző eljárást sorolunk fel. Nem tudunk és nem is szándékozunk a módszer komplex és általános prediktív modell kifejlesztésére vállalkozni. Ezen módszerek viszont alkalmasak a jelen vizsgálatba vont módszer továbbfejlesztésére. 


\section{3. ábra: KPI-tree alapú prediktív elemzés architektúrája}

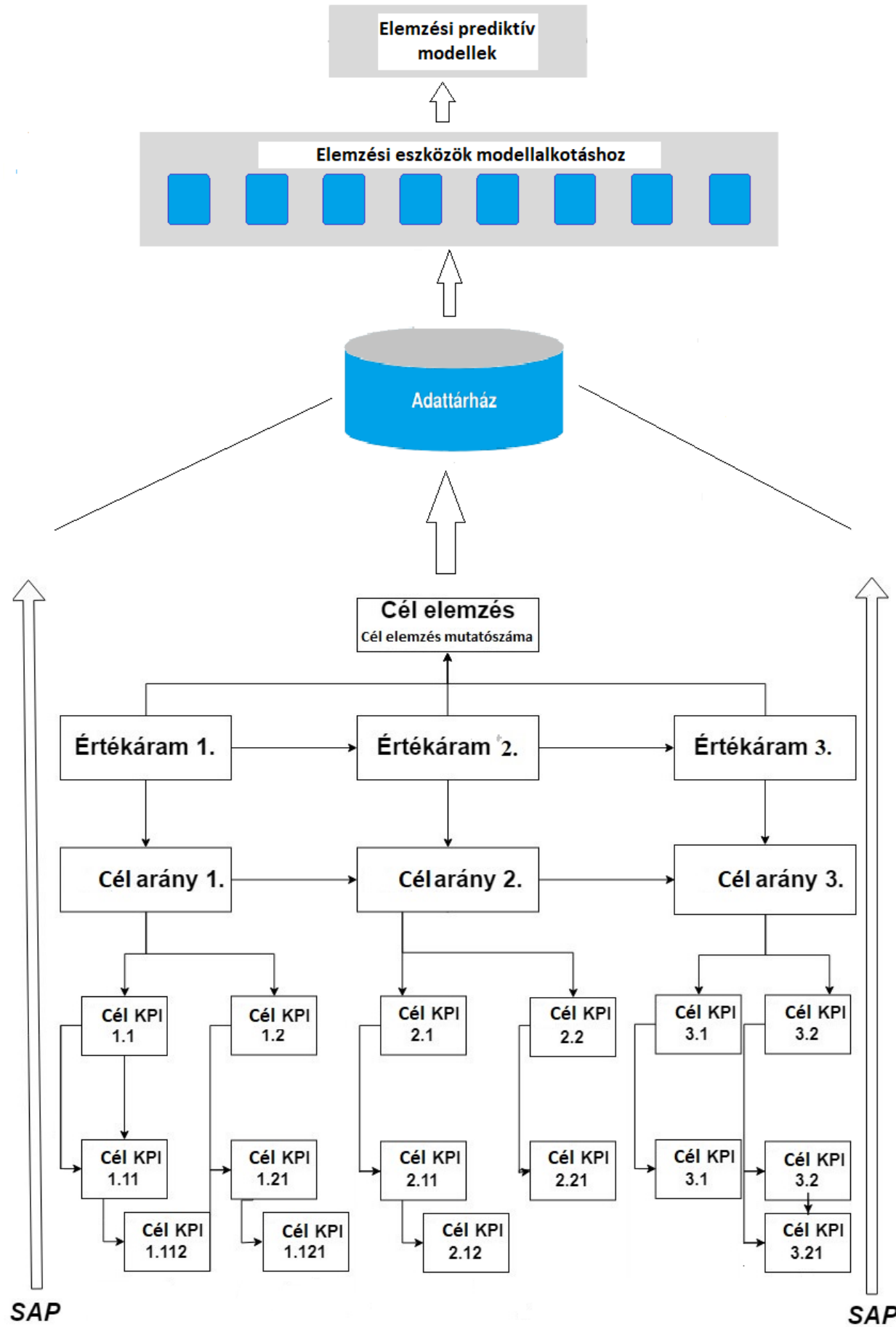

Forrás: A szerzők saját szerkesztése. / Ante et al. (2018) és Baars (2016) alapján 


\subsection{Neurális háló alapú prediktív modell}

A neurális háló úgy jellemezhető, mint egy a biológiai neurális rendszerek elvére felépített, párhuzamos és osztott müködésre képes információfeldolgozó eszköz. A hálók neuronokból állnak és a biológiai idegrendszerhez hasonlóan próbálja megvalósítani az információ felvételt, illetve feldolgozást. A problémák és feladatok megoldására tanulás útján jutnak el, ellentétesen a hagyományos algoritmikus eljárásoktól. A neurális hálók alapegysége a neuron. Ezek a neuronok olyan rendszert építenek fel, amely „n” bemenettel és „,m” kimenettel rendelkezik és amely az n-dimenziós bemeneti vektorokat m-dimenziós kimeneti vektorokká alakítja át az információfeldolgozás során (Álmos et al., 2002). Elmondható, hogy a neuronok rétegekbe szerveződve tevődnek össze, a neurális háló jellemzően három fö rétegből áll: a bemeneti, köztes és a kimeneti rétegből.

- Bemeneti réteg: Ezen rétegen belül olyan neuronok helyezkednek el, amelyek ismert információkból vagy a hálóba betáplált változókból állnak.

- Köztes réteg: Az input neuronok kapcsolatban állnak a köztes réteggel, ezen kapcsolatok a bemeneti neuronok fontossága szerint van súlyozva. Ezen súlyok a tanulás időszak alatt folyamatosan változnak.

- Kimeneti réteg: Eredményneuronok találhatók, ezek is súlyozottan kacsolódnak a köztes rétegben található neuronokhoz.

A neurális hálók a tanulást példákon keresztül végzik, csak úgy, mint a biológiai megfelelőik (Gurney, 1996). A tanulás során a bemeneti mintázatok alapján megváltoztatja a kapcsolatok súlyát, ezáltal pedig kialakul a háló végleges súlyozása. Amennyiben egy neurális hálót első alkalommal ellátunk adatokkal, a háló elkezdi véletlen találgatások mentén keresni a megoldást. A súlyokat a tanulás mentén a tényleges megoldástól való eltérés függvényében fogja módosítani. Ezt a folyamatot egy olyan iteratív eljárásnak nevezzük, amely során a neurális háló által végzett leképezést egy kívánatosnak vélt leképezéshez hasonlítjuk. Azonban fontos kiemelni, hogy kis minták esetén előfordulhat a túltanulás problémája. Túltanulás során nem az általános problémát tanulja meg a neurális hálózat, hanem a megadott adatbázis sajátosságait. Ennek elkerülése végett ketté kell osztani az adatbázist, tanulási és tesztelö mintákra. Kezdésként a tanuló adatbázison végezzük el a tanítást, majd futtassuk a tesztelő mintán is. Abban az esetben, ha a tanulási mintáéhoz hasonlóan a találati pontosság kedvező, akkor a tanulási folyamat eredményesnek értékelhető. Viszont abban az esetben, ha a tesztelő minta hibázása jelentős, akkor a neurális hálózat túltanulta magát (Kristóf, 2005).

A neurális háló súlyai jellemzően a backpropagation eljárás segítségével alakulnak ki. A neurális háló modell tanulási és tesztelő eljárása során állítható össze a sematikus összegző táblázat, melynek célja összefoglalni a minta hibáit, valamint besorolási pontosságát (Kristóf, 2002).

A neurális háló és a KPI-tree módszer közös alkalmazásával a bottom-up cél meghatározási módszer lehetségessé válik. Ezáltal pedig egy szakértői rendszert és egy objektív tervezési és elemzési rendszert biztosít a menedzsment számára. A különböző termelési, logisztikai és lean folyamatokhoz kötődő kontrolling rendszer egyik meghatározó funkcióját az erőforrás allokációt is kiválóan meghatározható 
prediktíven neurális háló segítségével. Ugyanakkor meghatározó a túltanulás kockázata, ami abból adódhat, hogy a KPI-tree módszerével megadott struktúra mentén gyüjtött adatok a neurális hálóba kerülve már csak az adott struktúra mentén felépülő tanulási mintázatoknak megfelelően fogja szolgáltatni a kimeneti értékeket. Ezért fontos a tesztelési fázis futtatása és annak folyamatos kiértékelése.

Összességében elmondható, hogy a napjainkban ismert eljárások közül a neurális háló alapú prediktív modell tekinthető a legpontosabb és legmegbízhatóbb predikciós elemzési módszernek, ezáltal pedig a legmegfelelőbben alkalmazható elemző eljárásnak.

\section{4. Összefoglalás}

A KPI-tree módszer egy hatékony, megfelelő és a többi komplex kontrolling módszerhez képest egyszerüen alkalmazható, a folyamatok és a hozzájuk tartozó költségek strukturálásában. A módszer alapvetően „mi történt” és „mi történik” kérdésekre ad választ, viszont arra, hogy „mi fog történni” és „mi kellene, hogy történjen" nem ad választ. Kutatásunkban teoretikus szempontból próbáltuk ezen problémát kielemezni és megoldást találni. A neurális háló és a KPI-tree módszer közös alkalmazásával a bottom-up cél meghatározási módszer lehetségessé válik. Ezáltal pedig egy szakértői rendszert és egy objektív tervezési, elemzési rendszert biztosít a menedzsment számára.

A fentiekben említett módszeren kívül számos eljárás alkalmazható KPI-tree módszerén alapuló prediktív elemzések végzésére. Általánosan azonban elmondható, hogy a KPI-tree módszer kialakítása és alkalmazása mindig szervezet specifikus, ezáltal nincs univerzális modell. Ebből következően a prediktív módszerek kiválasztása és alkalmazása esetén figyelembe kell venni a módszer sajátos jellemzőit.

\section{Köszönetnyilvánítás}

„Az Innovációs és Technológiai Minisztérium ÚNKP-19-3-I kódszámú Új Nemzeti Kiválóság Programjának szakmai támogatásával készültt."

\section{Irodalomjegyzék}

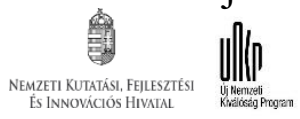

Álmos A., Győri S., Horváth G., Várkonyiné Kóczy A. (2002): Genetikus algoritmusok. Typotex Kiadó. Budapest.

Ante G., Facchini F., Mossa G., Digiesi S. (2018): Developing a key performance indicators tree for lean and smart production systems. IFAC PapersOnline, 51-11, 13-18.

Baars, H. (2016): Predicitve Analytics in der IT-basierten Entscheidungsunterstützung : methodische, architektonische und organisatorische Konsequenzen. Controlling: Zeitschrift für erfolgsorientierte Unternehmenssteuerung 3 (28): 174-180.

Babbie, E. (2013): The practice of social research (13th. kiad.). USA Belmont: Wadsworth, Cengange Learning.

Blumné B., K., Zéman Z. (2014): Controlling a vezetés szolgálatában. Történeti fejlödés, perspektívák, Gazdálkodás- és szervezéstudományi folyóirat A Virtuális Intézet Közép-Európa Kutatására Közleményei, 6 (1-2): 440-442. 
Boda Gy., Szlávik P. (2005): Kontrolling Rendszerek, KJK-KERSZÖV Jogi és Üzleti Kiadó Kft. Budapest, 224-235.

Gartner inc. (2017): Big Data. IT Glossary. <http://www.gartner.com/it-glossary/big-data/> (2020. 02. 27.)

Gulyás A. (2017): Forecasting 4.0: Miért érdemes a jövő előrejelzési módszerét használni?, Menedzsment és Controlling Portál, <https://www.controllingportal.hu/forecasting-4-0/> (2020. 03. 02.)

Gurney K. (1996): Neural nets. Department of Human Sciences. Brunel University. Uxbridge.

Kristóf T. (2002): A mesterséges neurális hálók a jövőkutatás szolgálatában. Jövőelméletek 9. BKÁE Jövökutatási Kutatóközpont. Budapest.

Kristóf T. (2005): A csődelőrejelzés sokváltozós statisztikai módszerei és empirikus vizsgálata, Statisztikai szemle, 83 (9): 845-846, 851-854.

Mayer-Schönberger V., Kenneth C. (2014:) Big Data- Forradalmi módszer, amely megváltoztatja munkánkat, gondolkodásunkat és egész életünket, HVG Kiadó Zrt., Budapest, 11-17.

Peral J., Maté A., Marco M. (2016): Application of data mining techniques to identify relevant key performance indicators. Computer standards and interfaces, 1-20.

Sanjay G., Howard G., Shun-Tak L. (2003): The Google File System Proceedings of the 19th ACM Symposium on Operating Systems Principles, ACM, Bolton Landing, New York, 20-43.

Schnellbach P., Reinhart G. (2015): Evaluating the effects of energy productivity measures on lean production key performance indicators. Procedia CIRP, 492-497

Stadller G. (2015): Big Data - tömeges adatelemzés gyorsan, HTE Medianet, 70 (1): 44-47.

Véry Z. (2012): Controlling - Menedzsment Fórum. <https://mfor.hu/cikkek/projektmenedzsment .html> (2020. 03. 17.)

White T. (2012): Hadoop: The Definitive Guide, Third Edition, O’Reilly Media, Inc. Sebastopol 17$22 \mathrm{p}$. 